\title{
Higher education in North Africa: comparative evolution of Algeria and Morocco
}

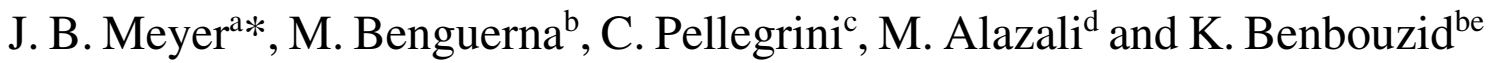

${ }^{a}$ Researcher CEPED, Institut de recherche pour le développement - IRD, Université de Paris, Paris, France ;*Correspondig author : jean-baptiste.meyer@ird.fr; ${ }^{\mathrm{b}}$ Researcher at Center for Research in Applied Economics for Development-CREAD, Algiers, Algeria; ${ }^{\mathrm{c}}$ Research Fellow, CNRS-IREMAM, Université d'Aix-Marseille, Aix-en-Provence, France, Diotime Education; ${ }^{\mathrm{d}}$ Researcher Faculté Polydisciplinaire de Safi, Laboratoire de recherche Innovations, Responsabilités et Développement Durable, Université Cadi Ayyad, Maroc; 'PhD Student Globalization and Economic Policies Laboratory, Université d'Alger3, Algiers, Algeria. 


\title{
Higher education in North Africa: comparative evolution of Algeria and Morocco
}

\begin{abstract}
The Maghreb countries share a similar demographic profile: around $40 \%$ of the population is under twenty-five years of age. The recent upsurge in the birth rate also implies, in the medium term, a large and lasting proportion of young people being in post-school phase and at the point of entry into working life. Considering these structural similarities, is the evolution of higher education going the same path among countries of North Africa? This article explores this question by examining detailed statistics for Algeria and Morocco. They reveal that the two countries have made different university policy choices, but that they are both affected by comparable transformations: the massification and feminisation of their enrolments; a relative emergence of the private sector, occurring recently but at different times; and substantial investments to generalise access for young people to university education, which is considered essential for development. These observations lead to a regional perspective with a prospective vision. A projection of recent trends over the coming decades, linked to demographic forecasts, is proposed. This exercise proves to be highly instructive in assessing the challenges that the situation poses to policymakers.
\end{abstract}

Keywords: higher education; North Africa; Algeria; Morocco; massification, feminisation; privatisation

\section{Introduction: Accelerated development of higher education in North Africa}

In view of the rapid expansion of youth on the African continent as well as the global sustainable development goals, the situation of higher education seems set to change (UNESCO 2015a, Zeleza 2017). In order to discern how it might evolve, it is useful to observe how it is changing, especially recently. Above all, it is necessary to differentiate by regions within the continent, while keeping a macroscopic dimension, capable of indicating international trends. 
When the respective situations of North Africa and Sub-Saharan Africa are distinguished, a significant difference emerges. While the proportion of the student population in the former is rapidly catching up with the world average (36\% of the age group), for the past two decades the proportion in the latter has plateauedi. Higher education enrolment in the north of the continent now concerns more than one in three young people, whereas this ratio is only one in ten in the south.

Within North Africa, this dynamic manifests itself in different ways depending on the country. Tunisia and Egypt started earlier than their neighbours. The former maintains a rather stable enrolment rate in higher education, while the latter has shown relatively moderate growth recently. In contrast, Algeria and Morocco's enrolment rates are increasing considerably and rapidly. Between the beginning and the end of the last decade, it increased from $30 \%$ to $45 \%$ for the former country and from $15 \%$ to $35 \%$ for the latter. In a short period of only 20 years, the student population increased fourfold. The observation of these transformations draws attention: how do they manifest themselves? What policies are at work? What social changes do they reflect or bring about?

This article intends to systematically study the two countries on the basis of mainly statistical, national, comparable and detailed data. This comparison sheds light on phenomena that are perceptible elsewhere: massification, feminisation, internationalisation and privatisation. The objective here is to document these situations as best as possible, in a quantitative empirical manner. The contrasting cases of Algeria and Morocco offer a novel perspective that opens up heuristic avenues for understanding and anticipating other situations of change in the rest of Africa.

After a description of the approach adopted, the sources mobilised and the methodology used, the article will address the massive evolution of university enrolments and the issues at stake, followed by its social, political and gender aspects; it will conclude by noting what the trends, particularly demographic trends, suggest as prospective lines for these countries themselves and for the North African region.

The approach: capturing trends in the evolution of higher education in Algeria and Morocco 
The objective of the research behind this article was to understand how higher education is evolving in Algeria and Morocco, in relation to their development issues. Beyond their geographical, linguistic and cultural proximity, these countries are comparable in many respects: population size, school enrolment, the importance of youth, a relatively similar Human Development Index (UNDP 2019) and a colonial history not without similarities.

The focus here is historical, covering a period from independence. But the observation and analysis focus mainly on the recent period, since the beginning of the 21 st century. At the turn of the 2000s, the strategy of a knowledge-based society and global economy began to permeate the discourses and practices of development policies in this region of the world. Research and higher education systems emerged as major components of growth, especially economic growth (Hanafi and Arvanitis 2016).

This does not mean that both Algeria and Morocco managed to transform their productive profile into knowledge-based economies. Investments made in higher education were indeed not matched by those in R\&D (research and development). Moreover, unemployability rates for higher education graduates remain higher than those for workers without diplomas, especially in Morocco ${ }^{\text {ii }}$. However, scientometric evidence shows a significant increase of academic output in Algeria and of innovation indicators for Morocco, during the last decade (UNESCO 2015b).

Beyond the knowledge mantra promoted internationally and prevailing in most of the development strategies around the world, this university expansion also responded to a demographic transformation: the coming of age of a large young population. Almost a quarter of the population was between 15 and 25 years old in 2000 in these two countries and in North Africa. The need to train them and integrate them into this new socioeconomy seemed inescapable, and the university is its primary agent.

In order to grasp these mass phenomena as a whole and in their dynamics, a quantitative study is essential. The use of regular and precise sectoral statistics is crucial. The specialised administrations of both countries make such figures available ${ }^{\mathrm{iii}}$. Each year they produce yearbooks in which they are carefully recorded. However, it is not always easy to access them, especially within a short period of time after the end of the years concerned. Both countries systematically collect and compile data from higher education institutions on an annual basis. However, both countries have particularities that have an 
impact on the collection of information. Algeria has a relatively homogeneous system, made up of mainly public institutions (mainly universities or university centres and some national higher or normal schools). Private higher education institutions have only been officially recognised very recently (as of mid-2017). There are only 14 of them and they still represent a very small number of students and teachers.

Morocco has a more diversified and complex system. The private sector has existed for several decades and represents between 5 and 10\% (depending on the year) of the total student population. It is fragmented into very disparate institutions, in terms of size, status and level. The public sector is divided between universities and non-university institutions and between open and selective courses. There are also institutions in PublicPrivate Partnership ${ }^{\text {iv }}$ which combine both statuses (e.g. the International University of Rabat). Although the Moroccan Ministry MENFPESRS (see note 2 above) centralises data on all these forms of institutions, the coverage of statistical information varies from one sector to another and complicates comparisons in some cases (Pellegrini, Alazali and Meyer 2020).

Despite differences in organisation and information between the higher education systems and institutions of both countries, many observations, descriptions and comparisons are possible and enlightening. The figures document precisely the evolution over the last two decades concerning: enrolments and graduations; distribution by disciplines, by gender and by level of study; teaching staff coverage and its characteristics; university social services, etc. An consistent panorama can thus be drawn up on the basis of these data, despite their limitations. The latter opens the way to qualitative, complementary and articulated analyses.

\section{Historical trends: a massive and recent increase in the student population}

In both Algeria and Morocco, university expansion did not take place immediately after independence. Certainly, both countries claimed and sought autonomy for their higher education capacities early on, even if they sometimes remained externally dependent for some time (Coulon 1976, Benguerna and Kadri 2014).

Algeria and Morocco initially followed an almost parallel and similar progression curve, before becoming particularly distinct at the turn of the year 2000 (Graphs 1 and 2). It was at this time (1999) that the two countries respectively entered a new political phase, 
with the end of the "black decade" in Algeria and a significant change in the monarchy in Morocco.

Figure 1. Algerian and Moroccan student population (1960-2020)

(Source: MESRS Algeria, MENFPESRS Morocco and Kleiche 2017)

Both countries decided to invest in the development of higher education. Algeria did so earlier and more strongly, given the high resources available. This was a period when the upward trend in hydrocarbon prices provided it with considerable budgetary leeway. In two decades, the number of - public - establishments increased from two dozen to more than a hundred. Indeed, after its independence, Algeria had only one university (University of Algiers) and two annexes installed in Oran and Constantine. Today the university network contains 108 higher education institutions covering the whole Algerian territory. In Morocco, if institutions also proliferated during this period, it was mainly through the private sector, where their size was minimal compared to those of the public sector which hardly multiplied. The absorption capacity of students has not increased to the same extent. However, it has developed fourfold in two decades in both countries, while Algeria is twice as large as Morocco today (1.8 vs 0.9 million). These remarkable growths are not, however, as exceptional as they seem. OECD countries went through almost identical phases of university expansion during the "trente glorieuses", between the end of the Second World War and the first oil shock.

Figure 2. Algerian and Moroccan student population (2000 - 2020)

(Source: MESRS Algeria, MENFPESRS Morocco)

This academic growth has required the growth of institutions, which have multiplied in a staggered manner in both countries. Morocco went from a single university after independence to 12 in the early 2000s, each with an even greater number of faculties. Public schools and, above all, public schools and universities increasingly complemented this system over the following two decades. In Algeria, especially from the end of the 1990s, the number of exclusively public institutions multiplied. While there was a single university in Algiers in 1962, there are now fifty four (54) universities, thirteen (09) 
university centers, nineteen (19) national schools, fifteen(15) schools and eleven (11) higher normal schools. (MESRS, 2021).

The university network has become denser and today covers the area of the country to a very large extent (maps 1 to 3). In Morocco, the public sector is present in many regions, while the private sector is essentially concentrated in the major cities. In Algeria, a radical choice was made to provide each of the 58 wilayas (prefectures) of the immense national territory (the largest in Africa) with at least one university establishment. This has led to the construction of a large number of infrastructures and buildings to ensure that young citizens have access to higher education from a reasonable distance from their homes.

Maps 1 and 2. Geographical distribution of higher education institutions in Morocco (2017)

(Source: Moroccan MENFPESRS ${ }^{\mathrm{v}}$ )

Map 3. Spatial and proportional distribution of students by wilaya in Algeria (2017)

\section{(Source: MESRS Algeria)}

The effort made by these countries to develop higher education is impressive. It corresponds to the demographic challenge of this plethora of young people that needs to be integrated. It also coincides with the global strategies set out in the speeches of international organisations (World Bank, OECD, UN, EU, UNESCO) of the global knowledge society, to which it conforms. This effort, however, also shows its limits, in a somewhat different way in both countries.

In Morocco, increased enrolment in universities has been hampered by the limited absorption capacity of the infrastructure. They are quickly saturated by a number of students that is much higher than the number of existing teaching places. Between 2008 and 2017, while the latter increased from just over 300,000 to almost 500,000, the student population rose from 300,000 at the beginning of the period to 800,000 at the end, exceeding the available places by almost 40\% (Pellegrini, Alazali and Meyer 2020). 
In Algeria, although the remarkable construction of numerous universities throughout the country has made it possible to meet the ever-increasing demand for postschool training, the difficulties have appeared in other ways. The quality of teaching is widely criticised by professors and students, according to numerous local testimonies ${ }^{\mathrm{vi}}$. It is also singled out by international rankings and academics (Ghouati 2019a).

In both countries, the increase in the number of students has not been matched by an equivalent increase in the number of teachers. In Morocco, the student/teacher ratio rose from 1:29 to 1:61 between 2009 and 2019 (compared to 1:20 in the OECD). In Algeria, the ratio has been rising very fast recently, from 22 students for one teacher in the middle of the decade to 25 for one three years later. Disparities between disciplines are considerable, with the ratio sometimes amounting to one teacher for more than 80 students in the social and human sciences. The problem of qualified and trained human resources for teaching is a challenge for both countries. It raises the whole question of advanced training, particularly doctoral training, and therefore, as a consequence, of research $^{\text {vii. }}$.

However, Master and Doctorate graduates are hardly numerous in Morocco: 13,500 and 2,100 respectively in 2017 , i.e. $1.7 \%$ and $0.25 \%$ of the number of students enrolled in higher education the same year. Admittedly, the number of students in these levels of training is increasing rapidly (200\% in 10 years) but at this rate and under optimal conditions, it would take at least 20 years to establish a student/teacher ratio close to the OECD average, keeping the current level of university enrolment constant...

In Algeria, there are many students enrolled in a Master's degree, between 300 and 400,000 depending on the year, and access to it is not very selective. Access to the Doctorate, on the other hand, has become more selective, with a difficult competition. Indeed, the number of doctoral enrolments was previously very high, up to 70,000 in 2016, but with a serious problem of them dragging on indefinitely. A reform that same year modified the conditions of access, the organisation of doctoral training and the duration of theses. The limiting factor for their successful completion, however, remains the research supervision. Although the university has a large number of laboratories, the consistency of the research activities carried out there is extremely variable. A recent evaluation by the Algerian Ministry even led to the closure of a good number of them. 
Finally, both countries can partially rely on doctoral students trained abroad. Algeria has nearly 1900 and Morocco 1350, in the European Union alone, in 2018 (Campus France 2019). As their graduation rate is high, they constitute a very substantial addition to the locally trained contingents, as doctoral degree is required for teaching position in both countries. In addition to this possible recourse to human resources from outside and from the diaspora ${ }^{\text {viii }}$, several factors contribute to supplying the teaching body with new vital forces. Among these, the rise in the number of women in the university population is not the least.

\section{Feminisation of the student body and teaching staff}

Since the beginning of the 21 st century, a major feature of the evolution of the academic institution has been its increased openness to women. However, it is not progressing at the same pace in both countries.

In Morocco, the period starts with a minority of women in higher education at all levels. In 2000, 45\% of undergraduate students at public universities were young women and only one third at higher levels. This disproportion is even more marked in schools and the private sector. But this situation has changed during the following two decades. The latest statistics (2018-19) show that $49.4 \%$ of enrolments in public universities and $47 \%$ in the private sector are women. Moreover, a female majority (51.4\%) emerges among new enrolments. In addition, women represent more than 55\% of the total number of students in the selective and professional courses.

At the higher, postgraduate levels, the proportion of women has increased from less than a third 20 years ago to $44 \%$ at the Master's level and $41 \%$ of doctoral students today. But the participation of these graduates in the teaching profession hardly seems to be increasing in the same proportions. It barely increased from $24 \%$ to $26 \%$ between 2000 and 2010 and then plateaued at that level until 2017, according to available figures.

In Morocco, therefore, the share of women tends to increase overall over time, but to decrease with the level of university education attained, as if the glass ceiling on academic progression by gender still existed.

Algeria, whose figures are more precise on these aspects, reveals a different evolutionary profile. At the end of the 1990s, parity was achieved in university 
enrolments. This was followed by a steady progression over the last two decades, leading today to a proportion of almost two-thirds of student enrolments in favour of women (see Figure 3). As their academic success rate is higher than that of men, women now represent a minority of barely one third of university graduates. This over-representation of the young, qualified female population is not an exceptional phenomenon: it is reflected in statistics from OECD countries and many others around the world (OECD 2019). However, enrolment and, even more so, graduation of women in Algeria reaches higher proportions than elsewhere.

It is also remarkable that it is not only the basic levels that are concerned but also the more advanced ones. While, at the beginning of the century, women did not take up the Master's degree - and rarely completed it successfully - this is no longer the case today. Their enrolment and success at this level are now equivalent to those at Bachelor's level. It is only at the postgraduate level (magister and doctorate) that their participation remains lower. Even so, their participation has just caught up with that of men $(50 \%$, at the end of the period, see Figure 3).

Figure 3. Evolution of the proportion of the female university population in Algeria, in percentages of total enrolled, graduates, advanced students and teaching staff (19972019)

\section{(Source: MESRS Algeria)}

Does this mean that the glass ceiling is disappearing in Algeria, if all student categories are inexorably feminised? Not completely, because if the majority of students are women today, it is still men who teach them more than half the time. But from a quarter at the end of the 1990s (a percentage identical to that of Morocco at the time), female teachers now represent more than $40 \%$ of the teaching staff. Above all, they are already more than half at the lower level (assistant professor) and close to parity at the intermediate level (lecturer). However, the status of professor remains strongly male, even if the increase in the proportion of women over the period is significant. The glass ceiling - which extends well beyond the academic sector - persists, but it is cracking and may eventually give way...

Finally, the gender distribution by discipline varies: while a female preponderance is evident in health, education and social subjects, the male preponderance is maintained 
in business, engineering and other so-called hard sciences. This distribution resembles that of Morocco but also that of the OECD countries. It reflects a certain transnational cultural homogeneity in the identification with educational and professional fields.

On the other hand, a comparison of the evolution of access to higher education by gender reveals important differences with sub-Saharan Africa as a whole. While the proportion of female students is increasing in the North, it is decreasing in the South, even though enrolment is increasing. According to UNESCO data ${ }^{\mathrm{ix}}$, in 1999 , the rate was $3.26 \%$ for women and $4.79 \%$ for men; in 2017 it rose to $7.54 \%$ for women and $10.46 \%$ for men. The gap has thus widened and among the 8 million African students (SSA), only $42 \%$ are women. Though not uniform, this trend in the region is significantly different from that of North Africa, which is in line with the majority of the countries in the world.

\section{Differentiated democratisation of access to knowledge}

The increased participation of women is part of the context of a proven student massification. This is linked to certain political choices. Reforms of higher education have been promoted since the independence of both countries, but especially during the last decades (see in particular Pellegrini et al. 2020 for Morocco and Ghouati 2019b for Algeria). Both countries invest an equivalent, non-negligible share of their budget in the sector: slightly above $1.1 \%$ of their respective GDP in the middle of the period, around 2010 (UNESCO 2015b) ${ }^{\mathrm{x}}$. However, this is reflected differently in the facilitation of access to knowledge in each of the two countries.

Social assistance for studies evolves in a different way in Morocco and Algeria. In the former, the number and proportion of students receiving grants started from a low base and have increased over the years. It has tripled in ten years (from 118 to 373,000), rising from $40 \%$ to $43 \%$ of the university population. Those receiving residential accommodation are a small minority (less than 10\%) and, although their numbers have increased significantly over the last ten years (from 35,000 to 58,000), they have not kept pace with the growth in numbers.

In Algeria, the number of students receiving grants increased fourfold between 1999 and 2010, reaching a coverage rate of almost $90 \%$ of students in the middle of the decade $^{\mathrm{xi}}$. Accommodation in university halls of residence shows an identical increase factor and concerns half of the total number of students over the same period. However, 
both the number of grant recipients and the number of students receiving accommodation have stagnated over the last 10 years - while the number of students has continued to rise - and their proportions have fallen to $60 \%$ and $30 \%$ respectively.

The effect of massification in both countries is very noticeable and weighs on the implementation of policies. Despite remarkable investments, the proportion of students benefiting from the system has not managed to take off in Morocco and is tending to decline in Algeria. The number of new entrants is added to a budget whose expansion is constrained. But this system reacts to different and asynchronous external pressures. In Morocco, the resources devoted to the social issue of students, initially limited, have increased, especially in the second decade of the 21st century, after the turn of the 2010 protests. In Algeria, on the other hand, the declining economy with plummeting hydrocarbon prices during the 2010s reduced the budgetary margins allowing for the generous policy of free tuition and generalised subsidies that previously prevailed (Meyer and Benguerna 2019). Today, in this country, the new governance hardly evades the issue of social works - whose management has been under scrutiny for several months - and that of an organised selection. The foundations of equal access are not in question, but the updating of its modus operandi seems unavoidable.

The language of instruction also poses problems that are often identical in both countries. In both Algeria and Morocco, scientific and economic courses are taught in French, while humanities courses have opted for Arabic. All selective access courses are taught in French. This poses a problem insofar as students have done most of their schooling in Arabic and are thus hardly prepared to study in French when they arrive at university. This leads to high drop-out rates, particularly in the first year of university, and generally to obstacles in understanding courses and learning throughout the Frenchlanguage university curriculum. The issue is politically sensitive in Algeria, where the choice of English as the international language of support is often supported in symbolic competition with French (Benguerna and Kadri 2001). The same issue also arises in Morocco in a more pragmatic way (Ben Haman 2020).

In the wake of the social management of student massification, the fundamental question facing both States is that of employment opportunities. The influx of young people to university certainly constitutes a space for socialisation in an economy where knowledge is important. Coordination between the university and the productive world 
therefore becomes crucial in order to create interdependence. How can we facilitate the professional integration of young people after their training in countries where qualifications are often more penalising than favourable - especially for young women, who have now graduated - according to numerous studies (Assad et al. 2018, Lassassi and Alhawarim 2018, Meyer 2019, Pellegrini et al. 2020)?

Quality is a major issue here. Employability depends on effective skills developed during the education process. In both the productive and the tertiary education sectors, many managers and teachers complain about the inefficiency of the mass system of higher education. The students themselves express their dissatisfaction with teaching conditions offered by the university. Quality is a concern for public policies which tempt to deal with it through normative, institutional measures. To address this issue, Algeria created the National Commission for the Implementation of Quality Assessment in Higher Education (CIAQUES) and Morocco the National Evaluation Institution (INE) in the early 2010. However, these formal endeavours, very much inspired by external experiences, require a great deal of adaptation in order to set up a culture of evaluation, assessment and accreditation. These quality control devices are crucial for modern labour markets to work efficiently, with skills identification, recognition and adequacy to potential jobs supply.

In both countries, associations and demands of unemployed graduates are being heard and carry significant weight in current social movements. It is illusory to expect that the economies of Algeria and Morocco can rapidly convert their activities to maximise the high-skilled share and thus build labour markets that absorb this newly skilled labour (Hanafi and Arvanitis 2016, Meyer 2019). But gradual, cooperative and iterative transformations between the academic and business spheres appear realistic. One option among others in this strategic direction could be the development of the private sector in higher education. It is taking shape in both countries, on a time scale that is also different but allows for useful comparisons.

\section{Private sector development: an option worthy of careful consideration}

The private higher education sector in Africa is generally developing later than elsewhere (Buckner 2017). In the three central Maghreb countries, institutions have been appearing since the end of the 20th century. However, it was at the turn of the millennium that the phenomenon took on a notable consistency. It became institutionalised, in fact, by coming 
under the official regulation of the ministries of higher education in Tunisia and Morocco (Mazzella 2011). It is therefore a recent and still limited transformation, insofar as the numbers involved are minimal (less than $10 \%$ of all students in both countries). This is even more the case in Algeria, where the first establishments only started to appear in 2017 , after an administrative gestation period of 10 years.

The development of a private higher education sector is a clear way to relieve budgetary constraints over public spending. Beyond these financial concerns, it is often presented as a possible solution to both the saturation of the public university and the unemployment of its graduates. Indeed, it would supposedly provide, on the one hand, an institutional complement to the training offer authorised by the public administration and, on the other hand, it would be intrinsically close to the business world and therefore to the employers of qualified labour. The examination of the Moroccan and Algerian situations is instructive from both points of view, as it provides empirical findings - albeit partial and temporary - at two stages of development: experimental in Algeria but more advanced in Morocco.

Today, there are nearly two hundred private Moroccan institutions listed ${ }^{\mathrm{xii}}$, with a variety of statuses and characteristics: schools of varying sizes, institutes, universities, and universities in public-private partnership. The number exceeds that of public schools, universities and faculties. It has varied from year to year since the first censuses in the late 2000s to the present day, but is hardly increasing (Pellegrini et al. 2020). These establishments remain highly concentrated in the large agglomerations and especially in Casablanca and Rabat-Salé, which account for more than two thirds of them. They do not spread much in the interior of the country.

The dynamics of their student recruitment is both remarkable and derisory: multiplied by four since institutionalisation in 2000 , the number amounts to a little more than 40,000 in 2017 , i.e. $5 \%$ of the public enrolment... This is an imperceptible growth for the system as a whole.

The private sector is a significant supporting force for only one of the three knowledge sectors in which it operates: management and commerce. In the other two science and technology and health sciences - it represents a very small fraction. It is absent from the other fields: humanities and social sciences, exact and natural sciences, etc. Its 
three fields of practice also correspond to regulated (selective) courses in the public sector. However, these are hardly the ones that are under pressure in terms of reception capacity (see above). They even have a surplus of available places, which are not filled because of a lack of candidates with the required level. Consequently, the private sector does not relieve the public sector of its burden but simply offers a complement in lighter courses.

The courses offered are intended to be professional in most cases. They are designed to lead to employment rather than to develop knowledge per se. The schools and establishments claim a high rate of integration of their graduates into the labour market, both in Morocco and in Algeria. This is indicated by the individualised followup of their former students. But the organisations' own teachers point out that their students come from privileged backgrounds, whose families have the means to pay for their enrolment in relatively expensive institutions. These families and their backgrounds also have the networks and introductions that open up employment, especially in skilled professions (Gérard 2008).

In Algeria, the same disciplinary dominance appears: it is mainly in commerce and management that the few institutions accredited since 2014 and 2017 operate. There are only about ten of them, among which only three operate in another field: electronics and mechanics, hotel and restaurant management, and foreign languages. The vocation of professionalism is clearly affirmed. The number of students amounts to a few hundred each for the moment. Job opportunities seem assured, for the same social reasons as in Morocco. Most of these establishments were already operating in a non-accredited form before and their accreditation has allowed them to develop. Their international links are frequent and their graduates can often also use their qualifications abroad (Bedaïda 2019). The state controls their activity and checks after three years whether they are complying with their specifications. This deadline is approaching for most of them, authorised since 2017. For the time being, the tiny number of graduates and the limited disciplinary and social components of their population cannot claim to make them a demonstrative option on a national scale.

It is clear that the private sector in both countries is hardly an immediate global solution to the twin problems of massification and employment. The numbers are not commensurate with the public sector; and the exclusivity of institutions with expensive 
access does not guarantee the intrinsic employability with which they would endow their graduates through a specific training perceived as professionalizing. In order to have a significant impact on these two issues, the private sector would have to train a much larger number of students, commensurate with the current plethora of young people in the region. However, the limiting factor is the resources of this population, only a small part of which can envisage assuming such training costs. By largely subsidising students in the private sector, as in Senegal, for example, the state can lighten the burden on the public sector and develop an alternative offer... but always at its expense (Goudiaby 2015)! Is this a viable long-term solution, if the aim of building an autonomous private sector lies precisely in the possibility of relieving the state of investments that are difficult to sustain? But the main virtue of increased private sector participation is perhaps to be found elsewhere than in a substitution - albeit partial - for the public sector: in the opening up of new pedagogical, organisational, technical, social and entrepreneurial options, likely to percolate and enrich the entire higher education system.

\section{Prospective: what would be the student numbers in the near future in North Africa?}

The orientations taken by the higher education systems of the Maghreb countries show a continuous increase, which is expected to continue in the years to come. By 2030, if current enrolment rates remain unchanged, student numbers in the region are expected to rise from just under 7 million today to over 8 million. If the growing trend continues, then the Maghreb will have almost 10 million students in 10 years (Table 1). The gap between women and men that has appeared over the last 15 years at regional level, and which is already perceptible today, except in Morocco, might continue to widen.

Table 1. Student population in Northern Africa in the coming years under different scenarios

(Source: UNESCO-ISU and United Nations statistics and population projections, processed by Andrainolo Ravalihasy, IRD-CEPED)

In ten years time, when the global Sustainable Development Goals (SDGs) are due to be achieved, student enrolment in the region will have grown by between 117 and $138 \%$, according to these two highly realistic scenarios. Indeed, the region is not far from the required indicators in terms of secondary school completion and universal access to post-secondary education (goal 4 , target 4.3 of the SDGs). With no limiting factors at 
entry and with a revival of the birth rate in the last two decades, the conditions are right for an increased demand for higher education in the short and medium term.

\section{Conclusion}

The transformations affecting Algeria and Morocco in a differentiated but comparable way mark out the possible futures of higher education in North Africa, taking into account the demographic profile of these countries and the isomorphisms of educational policies on a global scale. The evolution in Algeria and Morocco differs significantly: massification and feminisation are stronger and faster in the former, while privatisation is more important in the latter. However, several observations bring the two countries closer together:

- Firstly, the number of staff has considerably increased in the recent years;

- The proportion of young people in higher education is also increasing, especially for young women;

- $\quad$ support for higher education, particularly through social aid for studies, mobilises considerable public resources;

- the private sector is not currently able to compensate for the limitations of the public sector, both in terms of numbers and opportunities;

- the languages of instruction (Arabic, French, English) pose complex questions whose answers vary according to policy.

Finally, on the scale of the region as a whole, enrolments should continue to grow in line with those of Algeria and Morocco, but at a more moderate rate. This suggests a student population of between 8 and 10 million in 2030, depending on the scenario. This social force constitutes both a challenge and a resource for sustainable development in the region.

Acknowledgements : we are very grateful to our colleagues at both CEPED and CREAD for their comments on presentations about earlier versions of this article; we also especially thank suggestions and comments received from anonymous reviewer(s) of the journal. 


\section{References}

Assad, R., A. Hendy, M. Lassassi, and Y. Shaima. 2018. "Explaining the MENA paradox : rising educational attainment, yet stagnant female labor force participation", IZA Institute of Labor Economics, Discussion Paper Series, March.

Bedaïda, I. E. 2019. "L'émergence de l'enseignement supérieur privé en Algérie : contexte et gouvernance", Présentation de Thèse de doctorat, Ecole Nationale Supérieure de Management, CEPED, Paris 19 april 2019.

Ben Haman, O. 2020. "The Moroccan education system, dilemma of language and thinktanks : the challenges of social development for the North African countries", the Journal of North AfricanStudies, DOI: 10.1080/13629387.2019.1711061

Benguerna, M. and A. Kadri, eds. 2001, Mondialisation et enjeux linguistiques : quelles langues pour le marché du travail en Algérie, Alger : CREAD.

Buckner, E. 2017, "The Worldwide Growth of Private Higher Education: Cross-national Patterns of Higher Education Institution Foundings by Sector", Sociology of Education, 90 (4) : 296-314.

Campus France, 2019, "Les doctorants à l'international; tendances de la mobilité doctorale en France et dans le monde”, Les Notes, n60, july 2019.

Christoffels, A. 2019, “Africa needs another million Phd scientists to develop homegrown solutions", The Conversation, May 242019.

Coulon, A. 1976. “Où va l'université algérienne ?”, L’homme et la société, 39 (1) : 245266

Gérard, E. ed. 2008, Mobilités étudiantes Sud-Nord: Trajectoires scolaires de Marocains en France et insertion professionnelle au Maroc. Paris : PubliSud.

Ghouati, A. 2019a "Dévelopementalisme et enseignement supérieur : pourquoi l'Algérie n'a pas d'université ?" in L'Algérie au présent ; entre résistances et changements, edited by Dirèche K, 681-99. Tunis and Paris : IRMC-Karthala.

Ghouati, A., 2019b, L'enseignement supérieur en Algérie : entre contraintes politiques et défis socio-économiques. Paris : Editions Petra.

Goudiaby, J-A. 2015. L'université et la recherche au Sénégal ; à la croisée des chemins entre héritages, marché et réformes LMD. Louvain la neuve : Academia/l'Harmattan.

Hanafi, S. and R. Arvanitis. 2016. Knowledge Production in the Arab World, The Impossible Promise. London et New York : Routledge Advances in Middle East and Islamic Studies.

Jowi, J. O., 2021, "Doctoral training in African universities : recent trends, developments and issues ", Journal of the British Academy, n9s1, april 2021.

Kadri, A. and M. Benguerna. 2014. Ingénieurs en Algérie dans les années 1960 ; une génération de la coopération, Paris : Karthala. 
Lassassi, M. and I. Alhawarim. 2018. "Job search intensity and the role of Social Networks in Finding a Job in Arab Countries: a Case Study of Algeria and Jordan”. EMNES, Working Paper $\mathrm{n}^{\circ} 8$, March.

Mazzella, S. 2011. "Construction d'un marché international de l'enseignement supérieur privé au Maghreb" in Les mondes universitaires face au marché : circulation des savoirs et pratiques des acteurs, edited by Leclerc-Olive M., G. Scarfo-Ghellab, and A-C. Wagner, 105-116. Paris : Karthala.

Meyer, J-B. 2017. "MOOCset mobilités étudiantes : vers une nouvelle circulation des connaissances ? Observations au regard de l'Afrique Francophone." Journal of International Mobility, 5 (1).

Meyer, J-B., 2019, "Jeunesse, université, emploi : le triangle des inquiétudes ; cas de l'Algérie et comparaisons maghrébines." In Le travail mondialisé au Maghreb, edited by Benarrosh Y, 499-516. Rabat, Marseille, Casablanca: Editions La Croisée des chemins, IRD, Centre Jacques Berque.

Meyer, J-B. and M. Benguerna. 2019. "Higher Education and Human Resources Capacity Building in Algeria." International Journal of Technology Management and Sustainable Development, 18 (3) : 229-241.

Meyer, J-B., M. Pilon, and A. Ravalihasy. 2020. "Les effectifs étudiants en Afrique : évolution passée et exercice de projection." Working Paper du Ceped. " n47.

MESRS. 2012. L'enseignement supérieur et la recherche scientifique en Algérie; 50 années au serivce du développement. Alger: Ministère de l'Enseignement Supérieur et de la Recherche Scientifique.

OCDE. 2019. Regards sur l'éducation 2019; les indicateurs de l'OCDE. Paris: Organisation de Coopération et de Développement Economique.

Pellegrini, Ch., M. Alazali, and J-B Meyer. 2020. 'L'enseignement supérieur au Maroc ; état des lieux et comparaison public/privé” Working Paper du Ceped. " n46.

UNDP. 2019. Human Development Report 2019, Beyond Income, beyond average, beyond today: inequalities in human development in the 21st century, New York : United Nations Development Programme.

UNESCO. 2015a. Education 2030 ; déclaration d'Incheon et cadre d'action, Paris : Editions Unesco.

UNESCO. 2015b. World Science Report : towards 2030. Paris : Editions Unesco.

UNESCO, 2015c, How long will it take to achieve universal primary and secondary education? Technical Note, Paris : Editions Unesco.

Zeleza, P. T., 2017. "Positioning Universities as Engines of Innovation for Sustainable Development and Transformation", Journal of Higher Education in Africa, 15 (2) : 121. 


\section{Figures}

Figure 1. Algerian and Moroccan student population (1960-2020)

Figure 2. Algerian and Moroccan student population (2000 - 2020)

Figure 3. Evolution of the proportion of the female university population in Algeria, in percentages of total enrolled, graduates, advanced students and teaching staff (19972019)

Maps 1 and 2. Geographical distribution of higher education institutions in Morocco (2017)

Map 3. Spatial and proportional distribution of students by wilaya in Algeria (2017) 
Figure 1. Algerian and Moroccan student population (1960-2020)

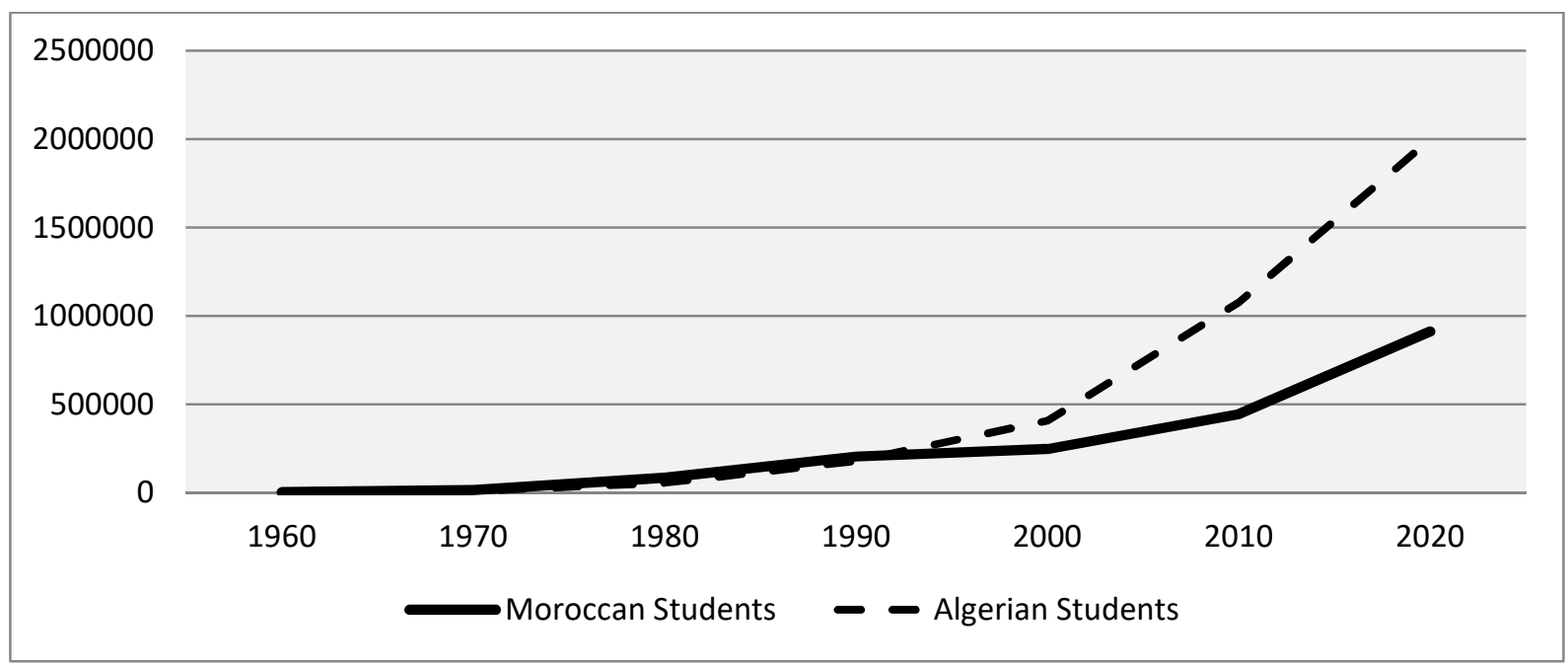

(Source: MESRS Algeria, MENFPESRS Morocco and Kleiche 2017) 
Figure 2. Algerian and Moroccan student population (2000 - 2020)

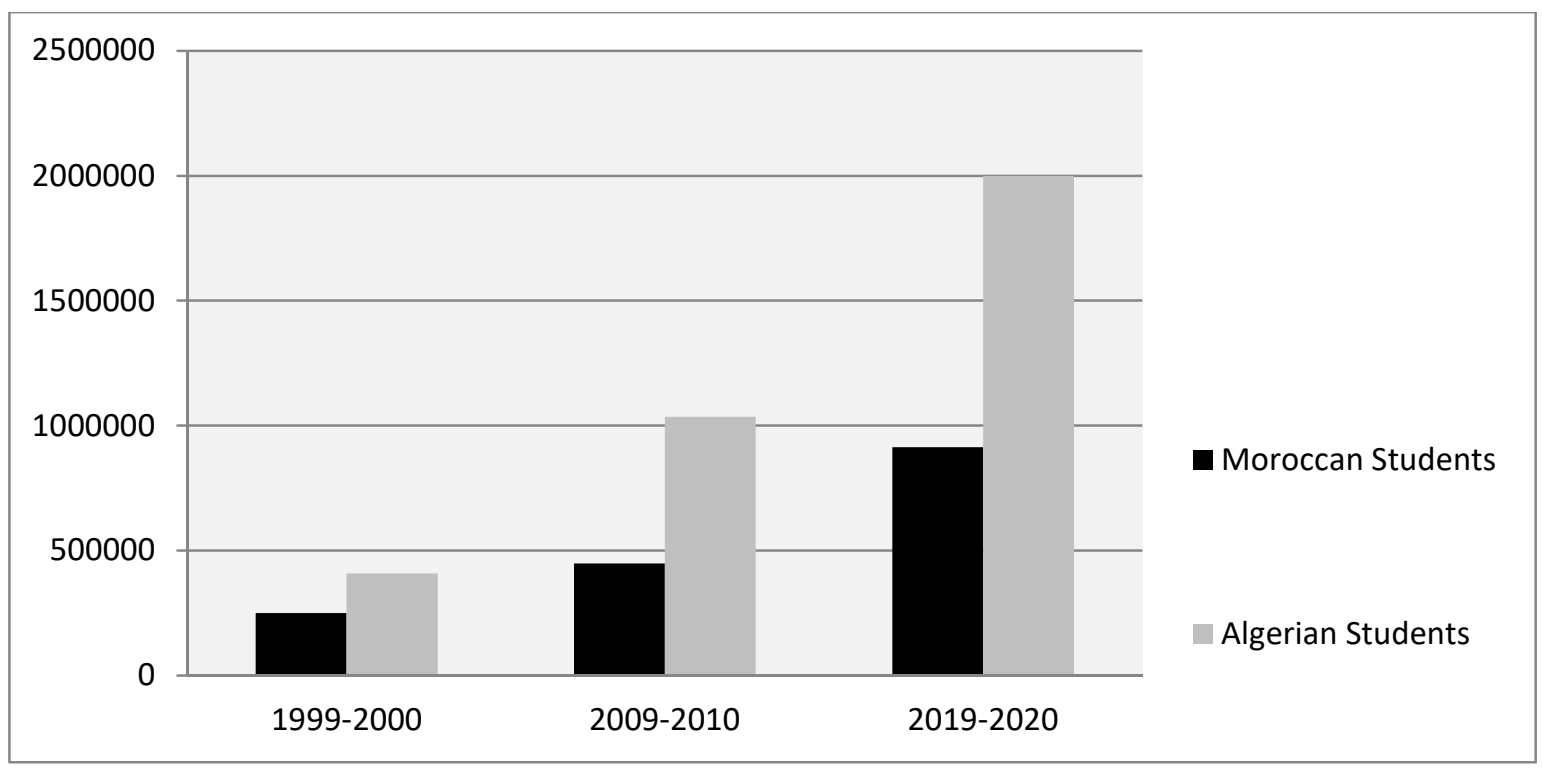

(Source: MESRS Algeria, MENFPESRS Morocco) 
Maps 1 and 2. Geographical distribution of higher education institutions in Morocco (2017)

Public Sector

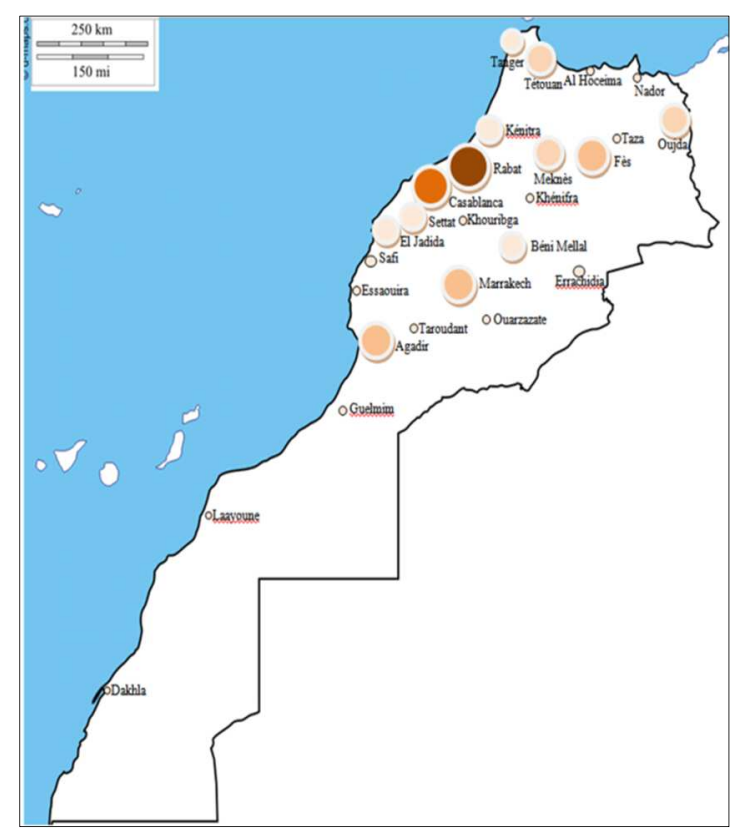

(Source: Moroccan MENFPESRS ${ }^{1}$ )
Private Sector

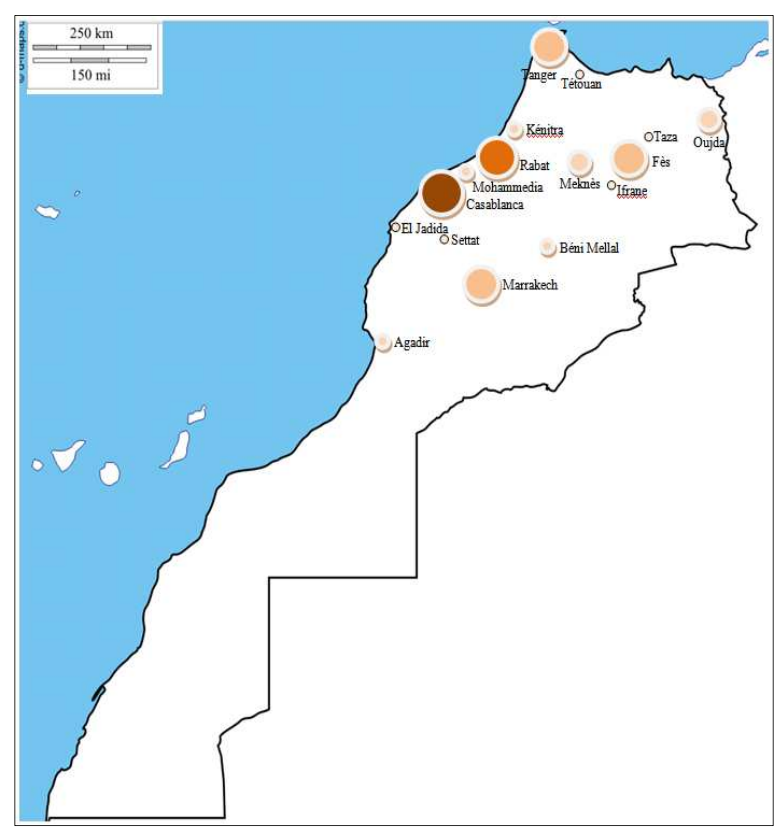


Map 3. Spatial and proportional distribution of students by wilaya in Algeria (2017)

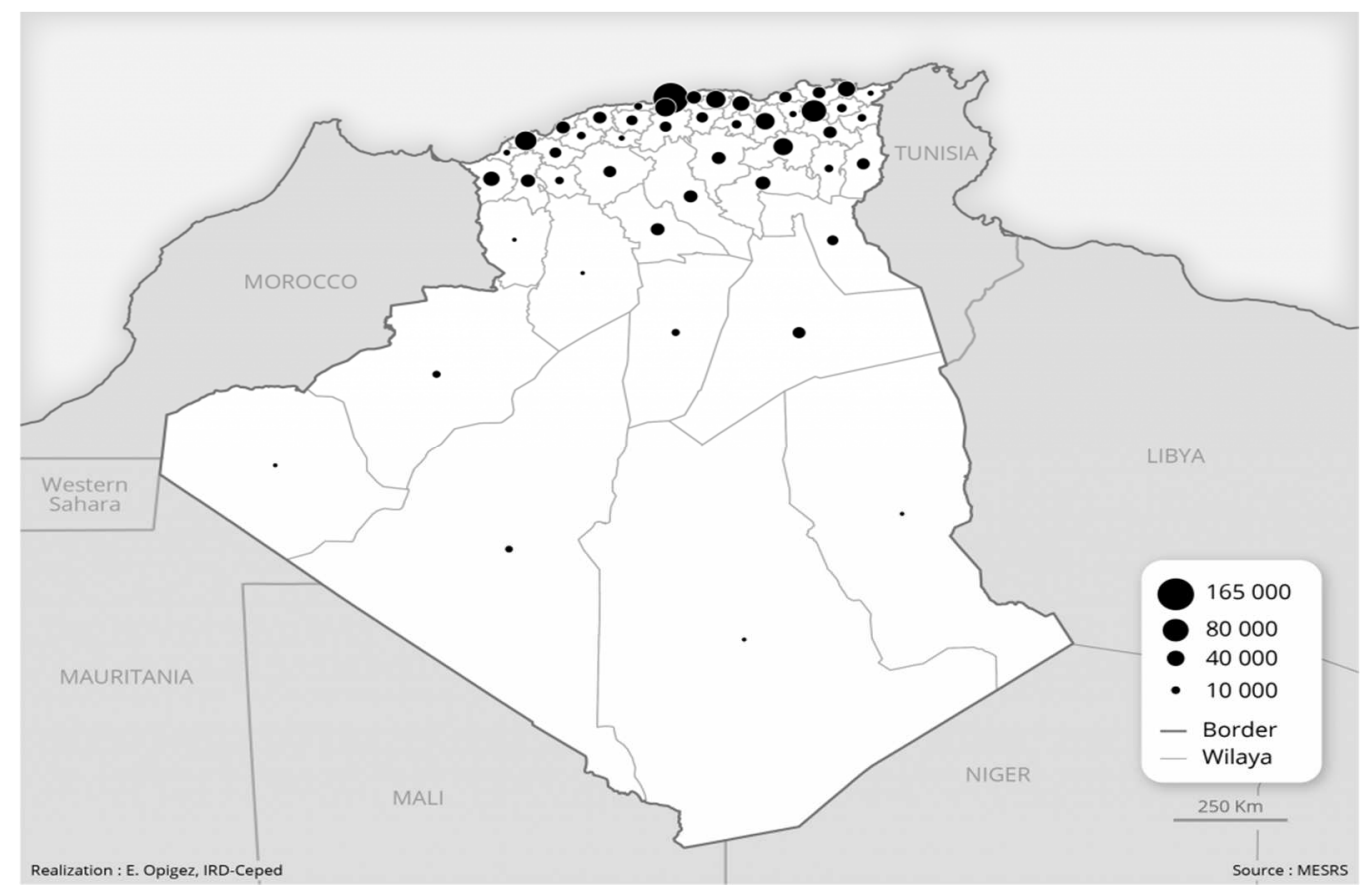

(Source: MESRS Algeria) 
Figure 3. Evolution of the proportion of the female university population in Algeria, in percentages of total enrolled, graduates, advanced students and teaching staff (19972019)

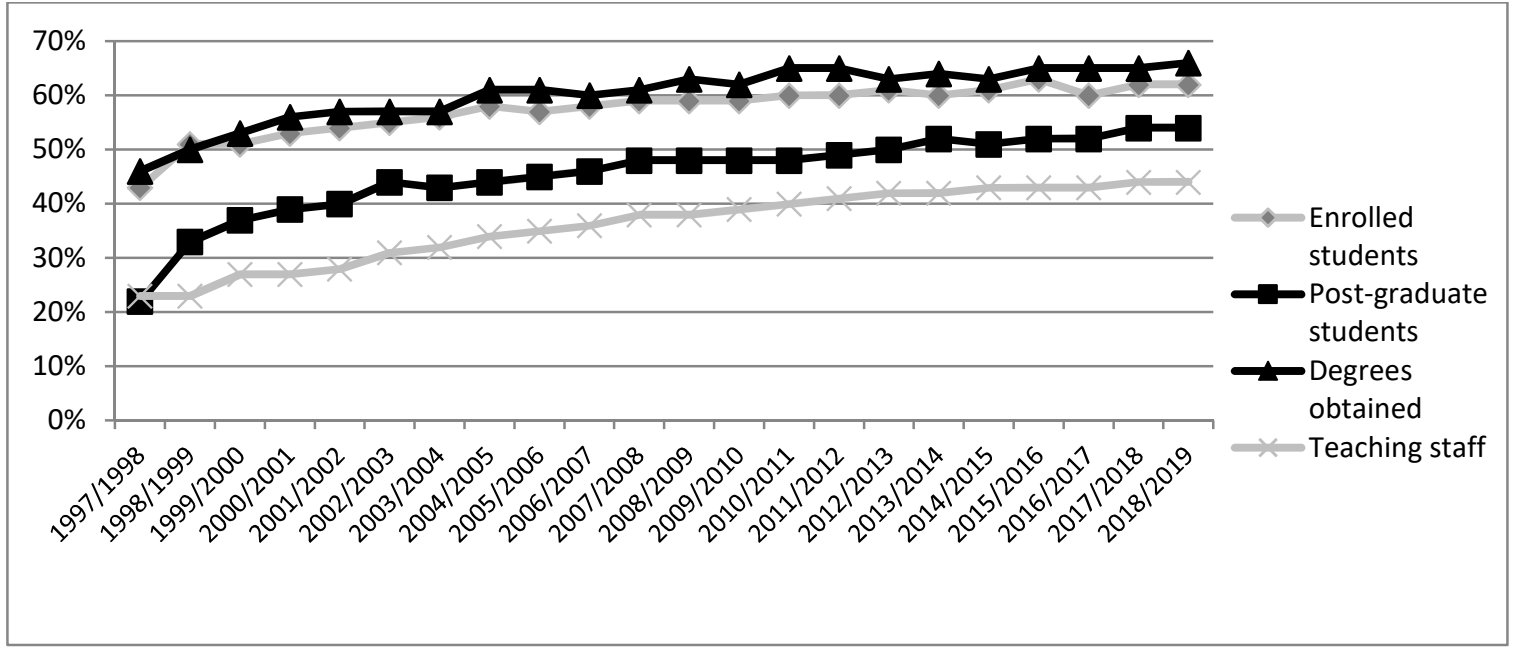

(Source: MESRS Algeria) 
Table 1. Student population in Northern Africa in the coming years under different scenarios

\begin{tabular}{|l|l|l|}
\hline Years & Scenario 1 & Scenario 2 \\
\hline 2018 & 6922973 & 6922973 \\
\hline 2019 & 6922275 & 6922275 \\
\hline 2020 & 6926460 & 7039495 \\
\hline 2021 & 6950868 & 7177735 \\
\hline 2022 & 6980507 & 7322258 \\
\hline 2023 & 7023397 & 7481864 \\
\hline 2024 & 7089997 & 7668516 \\
\hline 2025 & 7186237 & 7889882 \\
\hline 2026 & 7308628 & 8143530 \\
\hline 2027 & 7452639 & 8425613 \\
\hline 2028 & 7625591 & 8745589 \\
\hline 2029 & 7837249 & 9116232 \\
\hline 2030 & 8091098 & 9543548 \\
\hline
\end{tabular}

Scenario 1: maintenance of the current rate, Scenario 2: continuation of the current trend

(Source: UNESCO-ISU and United Nations statistics and population projections, processed by Andrainolo Ravalihasy, IRD-CEPED)

${ }^{\text {i }}$ Gross enrolment ratio in tertiary education, UNESCO-UIS figures 2018.

ii See the official statistics on unemployment rates according to the level of diploma in Morocco for 2021: https://www.hcp.ma/Taux-de-chomage-national-selon-le-diplome a267.html For instance during the 2021 second trimester, the unemployment rate for graduates was of $25.3 \%$ against $5 \%$ for workers with no diploma.

iii Statistical Yearbooks, Ministry of Higher Education and Scientific Research of Algeria; https://www.mesrs.dz/accueil

University Statistics, Ministry of National Education, Professional Training, Higher Education and Scientific Research of Morocco. https://www.enssup.gov.ma/fr/Statistiques.html

${ }^{\text {iv }}$ https://www.enssup.gov.ma/fr/Page/458-partenariat-public-priv\%C3\%A9.html

${ }^{v}$ https://www.enssup.gov.ma/fr/Statistiques.html

${ }^{v i}$ For example: Djamal Mimouni, "Is the Algerian University in decay? Un difficile état des lieux', El Watan, 10 July 2019 
${ }^{\text {vii }}$ On the scarcity of phd graduates with regard to student population and local research, see Christoffels 2019 and Jowi 2021

viii See Journal of Higher Education in Africa, vol 16, no 1 and 2, 2018

${ }^{\mathrm{ix}}$ http://data.uis.unesco.org/\#

${ }^{\mathrm{x}}$ For comparison, this investment is almost equivalent to that of the European Union countries in the middle of the decade (OECD 2019).

xi These often modest scholarships are accompanied by other aids such as transport, catering and health, which are often free or almost free and have not been increased for decades.

xii Private higher education in figures, 2016-2017 https://www.enssup.gov.ma/fr/Statistiques/3735- 